\title{
Forekomsten av fjelljo Stercorarius longicaudus på Hardangervidda
}

\author{
Frode Falkenberg, Terje Lislevand \& Kjell Erik Solheim
}

Falkenberg, F., Lislevand, T. \& Solheim, K.E. 2004. Occurrence of Long-tailed Skuas Stercorarius longicaudus at Hardangervidda. - Ornis Norvegica 27: 86-93.

In the Western Palearctic, the southernmost regular breeding area of Long-tailed Skuas is found at Hardangervidda mountain plateau, south Norway. Up to now, available information has indicated that the species only occurs in small numbers in this area (maximum four nests found in 1966). In 2001 and 2002 high abundances of small rodents were observed at Hardangervidda. We then found 12 and 9 nesting pairs of Long-tailed Skuas, respectively. In addition, one nest was found by other observers in both years, and several birds were observed in areas that we did not manage to cover, suggesting that at least 15 pairs may have bred in 2001 . The whole area was not covered in 2002, but observations of clutch size and nest density indicated similar numbers of breeding pairs. Most breeding pairs were in both years concentrated within an area of about $20 \mathrm{~km}^{2}$. The density here was similar to what is reported from more central parts of the species range in Fennoscandia (mean neighbouring distance $=815 \mathrm{~m}, 0.83$ pairs $/ \mathrm{km}^{2}$; Fig. 2). No birds were observed at all in 2003, probably due to very low small rodent abundance, although the area was only visited once this summer. Compared with previous reports, our observations suggest that the Long-tailed Skua population has increased at Hardangervidda during the last few decades.

Adresser: Frode Falkenberg, Department of Biology, University of Bergen, Allégaten 41, N-5007 Bergen, Norway.E-mail: falken@sisyfos.zoo.uib.no.Terje Lislevand, Department of Biology, University of Bergen, Allégaten 41,N-5007 Bergen, Norway.E-mail: terje.lislevand@zoo.uib.no.Kjell Erik Solheim, Norheimtunet 44A, N-5542 Karmsund, Norway.E-mail: kjelle_solheim@hotmail.com

Fjelljoen Stercorarius longicaudus har i hekketiden en sirkumpolar arktisk utbredelse. I Skandinavia finnes arten på høytliggende vidder og flyer i sørlige fjellområder, og i tilsvarende terreng helt ut mot kysten lenger nord (Cramp \& Simmons 1983, Vader 1994, Svensson et al. 1999). Hekkeforekomst og reproduktiv suksess styres i høy grad av tilgangen på smågnagere (Andersson 1971, 1976). I Norge har arten sin hovedutbredelse i de nordlige deler av landet der den også er mest tallrik (Gjershaug et al. 1994, Vader 1994). De sørligste hekkefunnene er gjort ved Hovden i Aust-Agder, der et par med reir ble funnet i 1982 og 1989, og et par ble observert i 1988 (Bengtson 1988, 1990). Det sørligste regulære hekkeområdet i landet vårt, og i Vest-Palearktis for $\varnothing v$ rig, finnes imidlertid innenfor de delene av Hardangervidda som ligger i Hordaland fylke (Haftorn 1971, Cramp \& Simmons 1983, Gjershaug et al. 1994, Vader 1994). Den første observasjonen av fjelljo som er kjent herfra i nyere tid ble gjort i 1934 (Haftorn 1971). Senere ble det også funnet enkelte reir, med opptil fire hekkende par i 1966 som det høyeste antall på en enkelt sesong (Haftorn 1971). Lite er kjent om artens forekomst på Hardangervidda etter 1970. I Hordalandsdelen av vidda ble arten kun funnet hekkende i én 10x10 km rute, sannsynlig hekkende i tre ruter og mulig hekkende i to ruter under atlasprosjektet (perioden 1970-1985; Gjershaug et al. 1994), noe som kan indikere at arten fortsatt opptrer sparsomt i dette hekkeområdet. Vi presenterer her observasjoner av fjelljoens opptreden på Hardangervidda i årene 2001-2003 som vesentlig øker kjennskapen til vår sørligste hekkepopulasjon for denne arten. 


\section{MATERIALE OG METODE}

For å få en oversikt over dagens forekomst av fjelljo på Hardangervidda unders $\varnothing$ kte vi sommeren 2001 fjellområdene som ligger mellom Riksveg 7 i nord og Nordmannslågen $\mathrm{i}$ sør. Vi konsentrerte leteinnsatsen rundt tidligere kjente hekkelokaliteter som er nevnt av Haftorn (1971). Det undersøkte området (ca. 200 km²) ligger i sin helhet innenfor Eidfjord kommune i Hordaland, der yttergrensene kan defineres ved å trekke en linje mellom Stigstuv i nordøst, Sandhaugområdet i sørøst, Nordvatn i sørvest og Dyranut via Sildabudalen i nordvest. En fullstendig oversikt over de arealene vi har inkludert i unders $\varnothing$ kelsen er vist i Figur 1. Fjelljoene på Hardangervidda viste seg å være knyttet til de samme hekkeområdene år etter år (egne observasjoner), og kan derfor bli spesielt utsatt for forstyrrelser fra mennesker. Vi har derfor valgt å ikke oppgi nøyaktig stedsnavn for våre observasjoner i denne artikkelen. Nøyaktig beliggenhet for alle funn er imidlertid rapportert til Norsk Hekkefuglatlas (www.fugleatlas.no).

Fjelljoen er relativt enkel å kartlegge i hekketiden da den gjerne varsler kraftig når en nærmer seg reirområdet, og dessuten ofte angriper inntrengere ved styrtdykking hvis en kommer nær egg eller unger (Andersson 1971). Vi lette derfor etter arten ved å gå gjennom potensielt hekkehabitat og speide etter flygende, sittende eller rugende fugler, ofte ved å benytte kikkert og teleskop fra utsiktspunkter i terrenget. Alle observasjoner og reirfunn ble kartfestet så nøyaktig som mulig. Unders $\varnothing$ kelsen ble gjennomført på i alt 15 feltdager fordelt på seks turer mellom 9. juni og 22. juli.

For å få et inntrykk av om antall hekkepar endret seg mellom år, bes $\varnothing$ kte vi områdene der fjelljo ble funnet det første året i de to påfølgende hekkesesongene. Vi sjekket da de fleste reirområdene fra det første året på turer i slutten av juni (2002) og midten av juli (2003).

\section{RESULTATER OG DISKUSJON}

Vi påviste i alt 12 hekkende fjelljopar innenfor studieområdet på Hardangervidda i løpet av sommeren 2001, noe som er tre ganger høyere enn tidligere rapporterte maksimumstall herfra. Av disse parene befant 11 seg ganske begrenset innenfor et ca. $20 \mathrm{~km}^{2}$ stort område (Fig. 2), heretter kalt kjerneområdet. De konkrete hekkefunnene besto av i alt ni reir med egg som alle ble funnet i tidsrommet 22. - 24. juni. Fordelingen av kullstørrelser var fem reir med to egg og tre reir med ett egg. Det siste reiret ble ikke sjekket for innhold, men rugende fugl ble observert på avstand med teleskop. Alle reirene lå på flat og relativt tørr grunn, og aldri oppe på de mange morenehaugene som finnes i området. I tillegg til reirene fant vi tre nye par 21. juli; også disse innenfor området der flesteparten av reirene ble lokalisert. Det ene av disse hadde to dununger, mens kun én dununge ble påvist hos hvert av de to andre parene. Disse tre siste parene var helt sikkert ikke noen av de som tidligere var påvist med egg, siden de befant seg ganske langt unna nærmeste kjente reir, og siden vi fant ungene til de fleste parene som tidligere var påvist med egg innenfor deres kjente reirområde. Unntakene var to par som sannsynligvis hadde mistet eggene eller ungene på et tidligere stadium. Det ene av disse hadde forlatt reirområdet da det ble sjekket på nytt 15. juli. Paret med reir med ukjent innhold nevnt ovenfor ble observert igjen 15 juli (varslet lite), men var forsvunnet ved et nytt bes $\varnothing \mathrm{k} 22$. juli, og unger ble ikke påvist her. Antall egg som ble lagt må ut fra dette være minst 18 , mens vi fant og ringmerket totalt 13 dununger (14., 15., 21. og 22. juli). Hos ett av parene som forsvarte en unge fant vi dessuten en ganske nylig død, og relativt liten, unge (1-2 uker gammel).

I tillegg til de konkrete hekkefunnene i 2001 observerte vi også ett par den 21. juli som varslet litt, men som trolig ikke hadde unger i nærheten, samt enslige fugler i ulike områder 23. juni og 22. juli (Fig. 2). Begge de sistnevnte ble sett på avstand, men ikke sjekket videre for eventuell hekking på grunn av tidspress. Den 11. juni så 


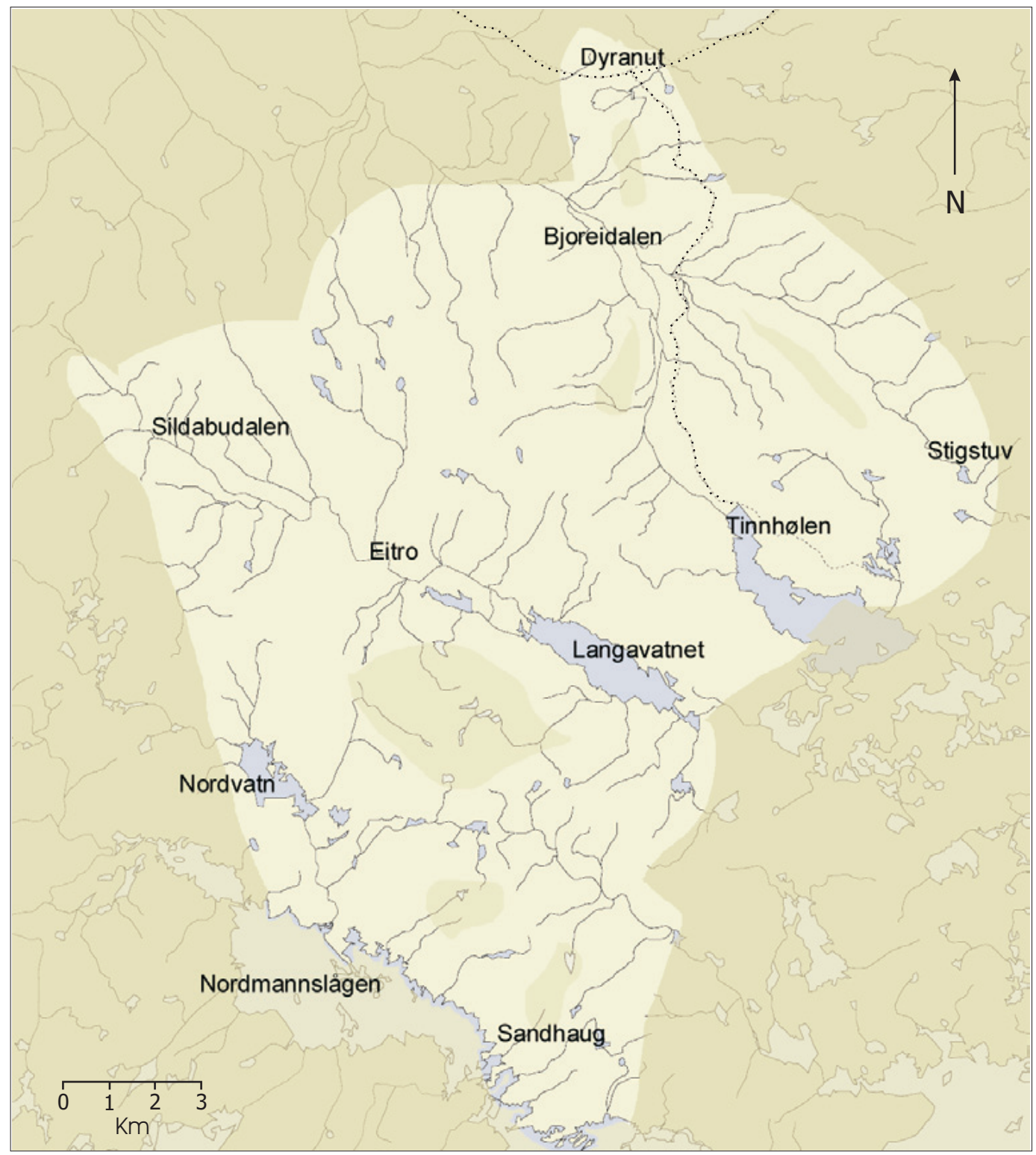

Figur 1. Oversiktskart for området på Hardangervidda som ble bes $\phi$ kt minst én gang for å lete etter hekkende fjelljo sommeren 2001, der de skyggelagte områdene viser arealer som ikke ble dekket av unders $\emptyset$ kelsen.

Figure 1. Map showing areas visited at least once to search for breeding Long-tailed Skuas at Hardangervidda during the summer 2001. Areas that were not covered by the investigation are shaded. 


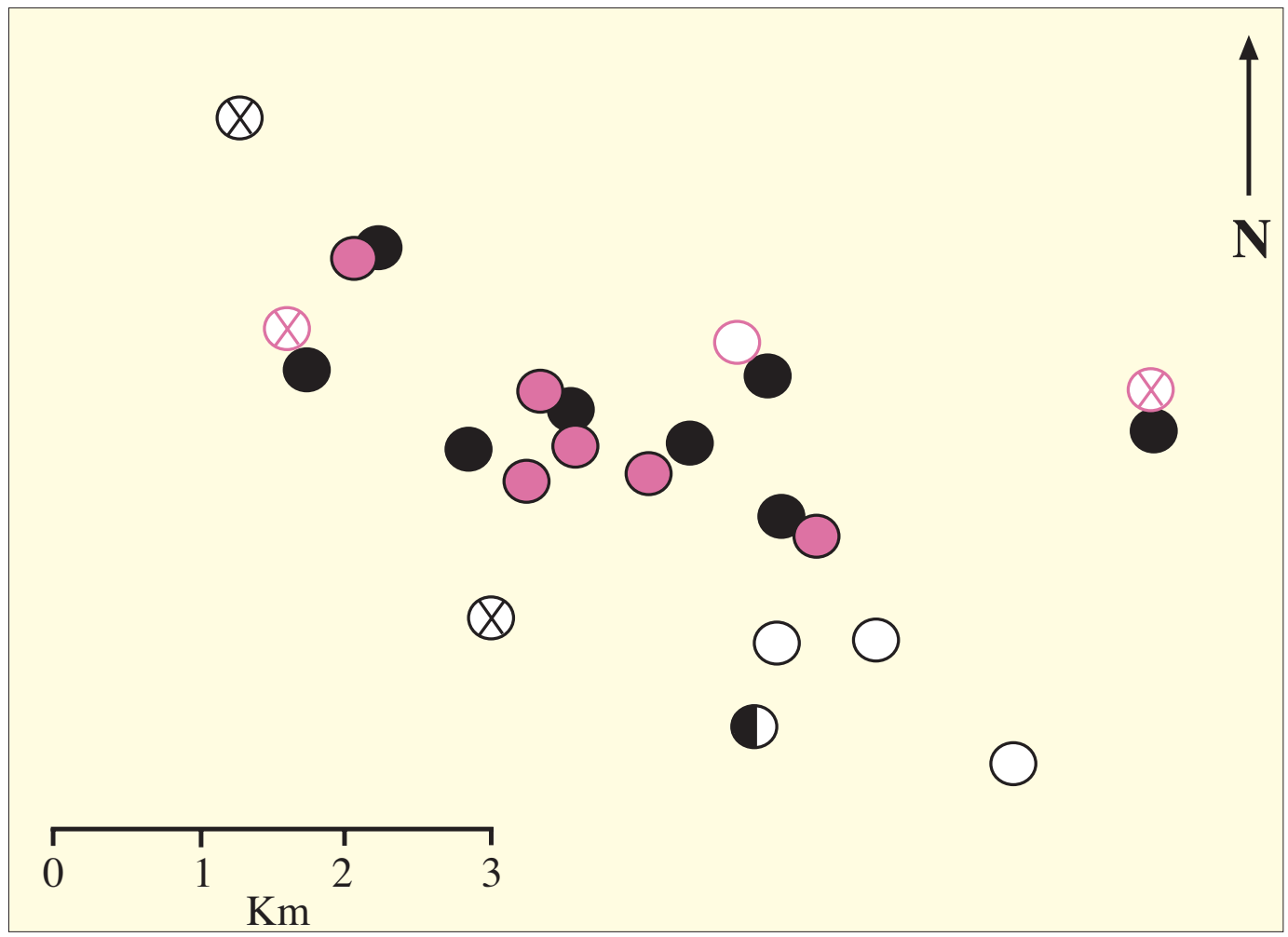

Figur 2. Plasseringen av fjelljoreir innenfor kjerneområdet på Hardangervidda sommeren 2001 (svarte symboler) og 2002 (røde symboler). Kartet viser reir funnet med egg (fylte sirkler), par med unger (åpne sirkler), par uten reir (halvfylt sirkel) og enkeltindivider som trolig ikke kom fra noen av reirene som her er markert (sirkel med kryss).

Figure 2. Nest placement of Long-tailed Skuas within the core of our study area at Hardangervidda during the summer 2001 (black symbols) and 2002 (red symbols). The map shows nests found with eggs (filled circles), pairs with young (open circles), pairs without nest (half-filled circle) and single birds that probably did not originate from any of the nests shown here (circles with cross).

vi dessuten en enslig fugl i et annet område der Stein Nysæter (pers. medd.) fant et par med reir både sommeren 2000 og 2001. To spredte observasjoner av småflokker (antakelig ikkehekkende, eller fugler som hadde avbrutt eller mislyktes med årets hekking) ble dessuten gjort av oss og andre observatører i løpet av juli måned. Dette gjelder flokker med fem adulte fugler ved Jenglebotn 14. juli og fire adulte fugler sørøst for Trondsbunuten 17. juli. Ut fra observasjonene nevnt over er det sannsynlig at minst 15 par fjelljo startet hekking innenfor det unders $\varnothing$ kte området sommeren 2001.
På en tur 23. - 26. juni 2002 besøkte vi igjen kjerneområdet der i alt 11 reir og/eller kull ble påvist året før. Denne gangen fant vi seks fjelljoreir, alle med to egg. I tillegg fant vi et par med en nyklekket unge 25 . juni. I to av reirene ble klekking påvist 24. juni, noe som sammen med ungefunnet tyder på en noe tidligere fenologi denne sesongen enn året før. Samtlige reir, og ungen, lå i kort avstand fra der reirene ble påvist i 2001. I tillegg så vi ett enkeltpar som tilsynelatende ikke hekket, og to individer med usikker hekkestatus. Områdene hvor tre kull ble funnet først på ungestadiet i 2001 (Fig. 2) ble ikke 
besøkt i 2002. I et område der vi fant et par med to egg i 2001 ble reir med to egg også funnet 12 . juni 2002 (Ole Aa. Brattfjord, pers. medd.). Dette paret mistet trolig eggene siden vi observerte dem i reirområdet 23. juni 2002, men uten at de da viste tegn til hekking.

Sommeren 2003 ble kjerneområdet besøkt kun én gang; på en dagstur 19. juli. Innenfor et område der henholdsvis åtte og seks reir ble funnet de to foregående årene, påviste vi nå ingen fjelljo i det hele tatt.

I motsetning til hva som tidligere var kjent, viser våre observasjoner fra Hardangervidda at fjelljoen kan opptre i betydelige antall også i dette som må betegnes som et randområde for arten i Vest-Palearktis. Siden fjelljoen opptrer årvisst i hekkeområdet, men kun legger egg i sesonger med gode næringsbetingelser (Andersson 1971), antar vi at fjelljoen hekker regelmessig innenfor det unders $\varnothing$ kte området. Den sparsomme informasjonen om artens forekomst her de siste årene skyldes trolig at området har blitt lite besøkt av ornitologer. Våre feltobservasjoner tyder på at både 2001 og 2002 var gode smågnagerår på Hardangervidda. Under snøsmeltingen i begynnelsen av juni 2001 var det vanlig å se vinterspor etter smågnagere $\mathrm{i}$ form av ganger $\mathrm{i}$ jorda, vinterbol og ekskrementer. Videre gjorde vi daglige observasjoner av mus (for det meste Microtus sp.), mens lemen Lemmus lemmus ikke var vanlig å se. I løpet av 18. og 19. mai 2002 så vi i alt 13 lemen på snøen mellom riksveg 7 og Stigstuv. Resultater fra et standardisert fangstprosjekt ved Universitetet i Bergen som overvåker smågnagerbestandene på Vestlandet om sommeren (Göran Högstedt pers. medd.) underbygger vårt inntrykk av at disse to sesongene var gode smågnagerår. Siden prosjektets oppstart i 1995 har nemlig ikke fangsttallene av fjellrotte Microtus oeconomus vært høyere i fangstfeltene ved Tinnhølen enn sommeren 2001. Også i 2002 var det bra med gnagere i fellene, men nå primært lemen. Sommeren 2003 viste imidlertid fangsttallene at det var et bunnår for smågnagere i området. De relativt høye antallene med fjelljoreir som vi fant i 2001 og 2002 ser derfor ut til å være representative for toppår for arten på Hardangervidda.

Våre undersøkelser viser at utbredelsen til fjelljoen er svært lokal på Hardangervidda. Konsentrasjonen av reir innenfor kjerneområdet er et påfallende trekk ved fjelljoens forekomst her. Også tidligere observatører (Hagen 1960, Haftorn 1971) har påpekt artens lokale forekomst i dette fjellområdet, men da basert på atskillig færre reirfunn, og uten at det går fram hvorvidt observatørene har undersøkt andre deler av vidda. Tettheten av reir i kjerneområdet var sammenlignbart med det som er kjent fra områder der arten har sin hovedutbredelse $\mathrm{i}$ Norden. I 2001, da flest par ble påvist, fant vi her en tethet på 0,83 par $/ \mathrm{km}^{2}$ (10 par på 12 $\mathrm{km}^{2}$ ). Gjennomsnittlig naboavstand var $815 \mathrm{~m}$ ( $\mathrm{n}=10$; Fig. 2). Tilsvarende tetthet funnet under gode smågnagerår i Nord-Sverige er 0,63 par/ $\mathrm{km}^{2}$ (Andersson 1976). Ut fra våre observasjoner av smågnagere, og spor etter disse, er det ingenting som tyder på større næringstilgang innenfor kjerneområdet enn andre steder på Hardangervidda sommeren 2001. Årsaken til fuglenes preferanse for dette området er derfor uklar.

Området som vi undersøkte sommeren 2001 ble i perioden 1930-1970 hyppig besøkt av ornitologer, blant annet på leting etter hekkende snøugler Nyctea scandiaca (Hagen 1952, Haftorn 1971), og det er etter vår oppfatning liten grunn til å anta at fjelljoen i særlig grad ble oversett eller underrapportert da. Sammenlignet med det lave antallet hekkende par som er kjent fra forrige århundre kan derfor våre observasjoner indikere at fjelljoen har økt i antall på Hardangervidda de siste femti år.

\section{TAKK}

Vi takker Trond Einar Brobakk, Torbjørn Idland, Lars Erik Johannessen, Geir Richard Kallestad, Geir K. Knudsen, Ingvar Måge og Tobias Roth for assistanse under feltarbeidet, samt Lars 
Liseth for velvillig utlån av hytte. Takk også til Bjarne Andersen, Ole Aa. Brattfjord, Göran Högstedt, Stein Nysæter og Njål Inge Tjensvoll som alle velvillig har bidratt med opplysninger til denne artikkelen. Göran Högstedt takkes dessuten for nyttige kommentarer på et tidligere manuskript. Unders $\varnothing$ kelsen ble finansiert av NOFs snøuglefond.

\section{SAMMENDRAG}

\section{Forekomsten av fjelljo Stercorarius longicaudus på Hardangervidda}

Det sørligste regulære hekkeområdet for fjelljo i Vest-Palearktis finnes på Hardangervidda i Sør-Norge. Fram til i dag tyder tilgjengelig informasjon på at arten forekommer i lite antall i dette området (maks. fire reir i 1966). I 2001 og 2002 ble det påvist gode forekomster av smågnagere på Hardangervidda. Disse årene fant vi henholdsvis tolv og ni hekkende par; de fleste innenfor et areal på rundt $20 \mathrm{~km}^{2}$. Sammen med andre observasjoner av fjelljo i området tyder dette på at så mye som femten par hekket i 2001. Området ble ikke like godt dekket i 2002, men reirtetthet og kullstørrelse indikerer at bestanden var tilsvarende stor også dette året. Våre funn kan tyde på at fjelljobestanden har $\varnothing \mathrm{kt}$ på Hardangervidda de siste tiårene.

\section{REFERANSER}

Andersson, M. 1971. Breeding behaviour of the Long-tailed Skua (Stercorarius longicaudus Vieill.). Ornis Scand. 2: 35-54.

Andersson, M. 1976. Population ecology of the Long-tailed Skua (Stercorarius longicaudus Vieill.). J. Anim. Ecol. 45: 537-559.

Bengtson, R. 1988. Fuglenes hekkeutbredelse i AustAgder. Sluttrapport Atlas-prosjektet 19701985. NOF avd. Aust-Agder.

Bengtson, R. 1990. Smågnageravhengige fugler i Aust-Agder i 1988 og 1989. Larus marinus 19: 23-47.

Cramp, S. \& Simmons, K.E.L. (eds.). 1983. The Birds of the Western Palearctic. Vol. 3. Oxford University press, Oxford.
Gjershaug, J.O., Thingstad, P.G., Eldøy, S. \& Byrkjeland, S. (red.) 1994. Norsk fugleatlas. Norsk Ornitologisk Forening, Klæbu. 551 s.

Haftorn, S. 1971. Norges Fugler. Universitetsforlaget, Oslo.

Hagen, Y. 1952. Rovfuglene og viltpleien. Universitetsforlaget, Oslo.

Hagen, Y. 1960. Gjess, fjelljo og endel andre fugler på Hardangervidda sommeren 1959. Sterna 4: 33-36.

Svensson, S., Svensson, M. \& Tjernberg, M. 1999. Svensk fågelatlas. Vår făgelvärld suppl. 31, Stockholm.

Vader, W. 1994. Fjelljo. S. 154-155 i Gjershaug, J.O., Thingstad, P.G., Eld $\varnothing y$, S. \& Byrkjeland, S. (red.). Norsk fugleatlas. Norsk Ornitologisk Forening, Klæbu.

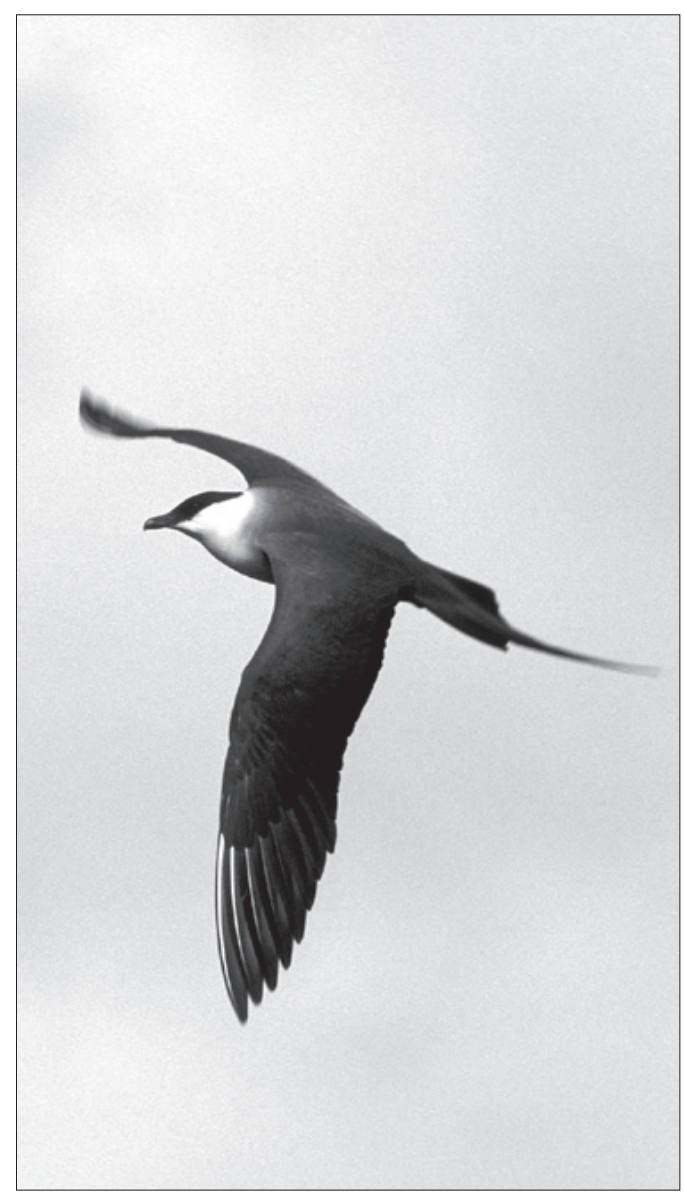

Voksenfjelljo Stercorarius longicaudus på Hardangervidda juli 2001. Foto: Frode Falkenberg. 


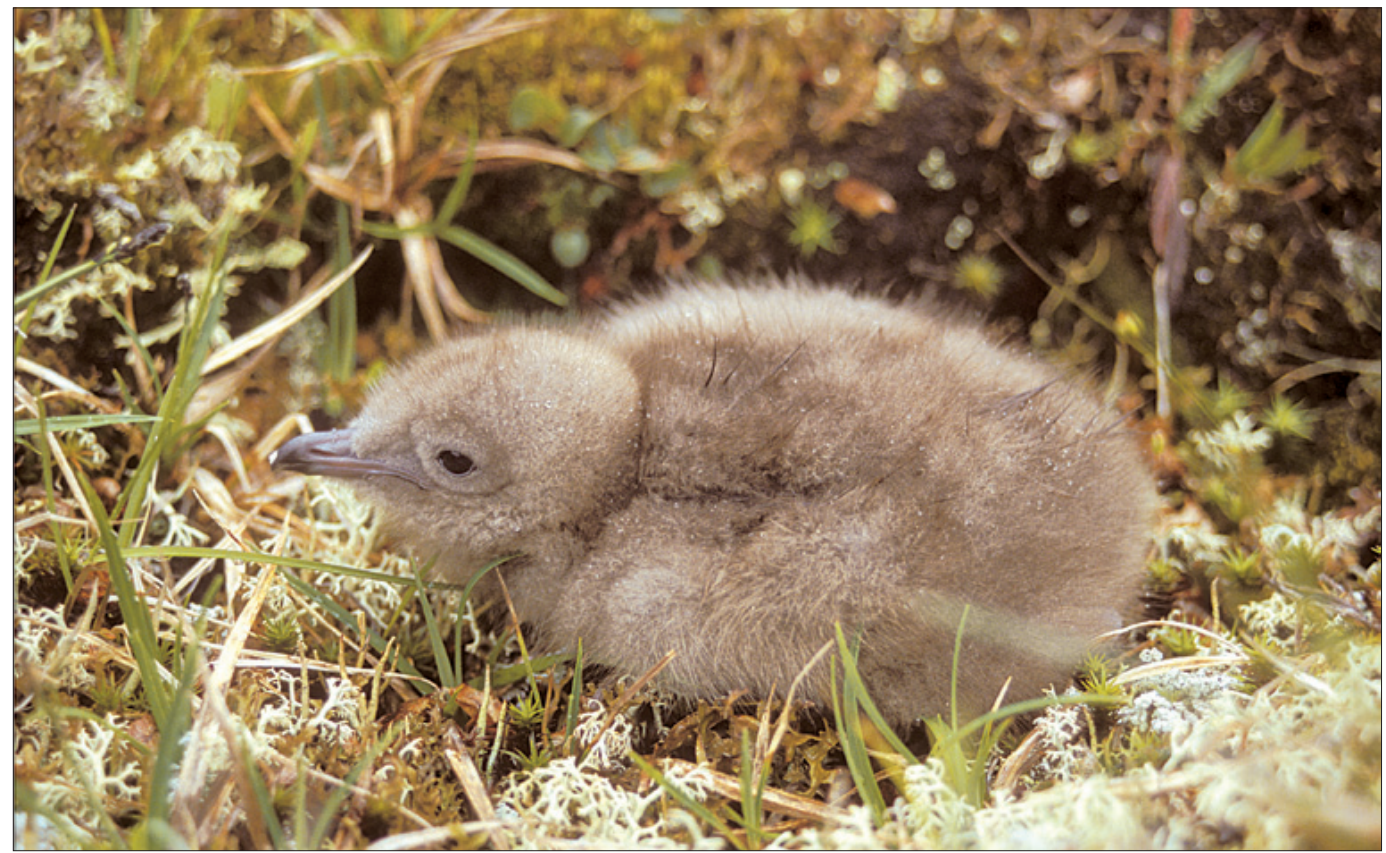

Fjelljo Stercorarius longicaudus pullus på Hardangervidda juli 2001. En av foreldrene til dette ukesgamle individet er avbildet på side 91. Paret la to egg, men kun en unge var igjen seinere på sesongen. Foto: Frode Falkenberg.

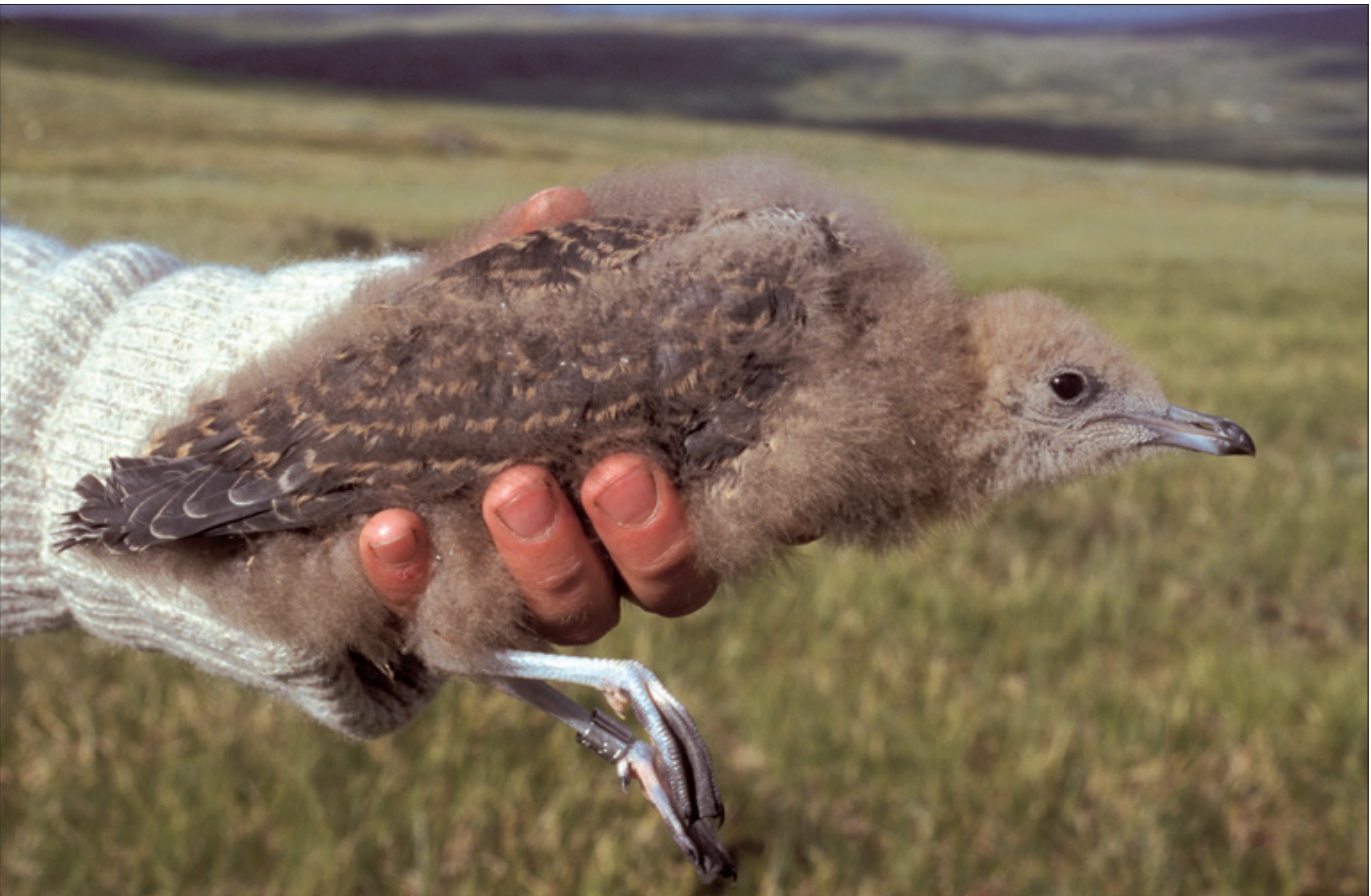

Fjelljo Stercorarius longicaudus pullus på Hardangervidda juli 2001. Fuglen er 2-3 uker gammel. Foto: Frode Falkenberg. 


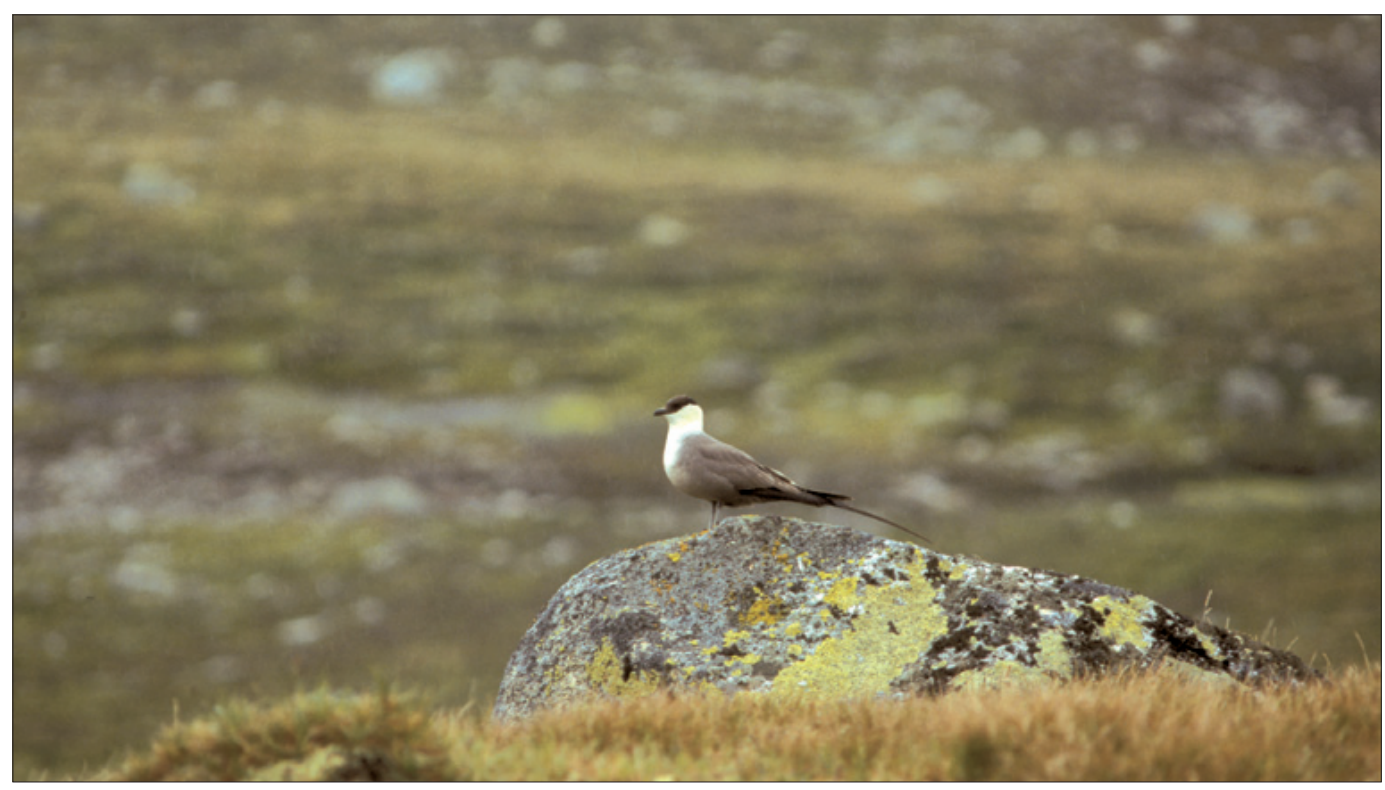

Koller og hauger i terrenget er foretrukne sitteplasser for den ikke-rugende voksenfuglen. Da har de god oversikt og kan lett oppdage potensielle farer på lang avstand. Foto: Frode Falkenberg.

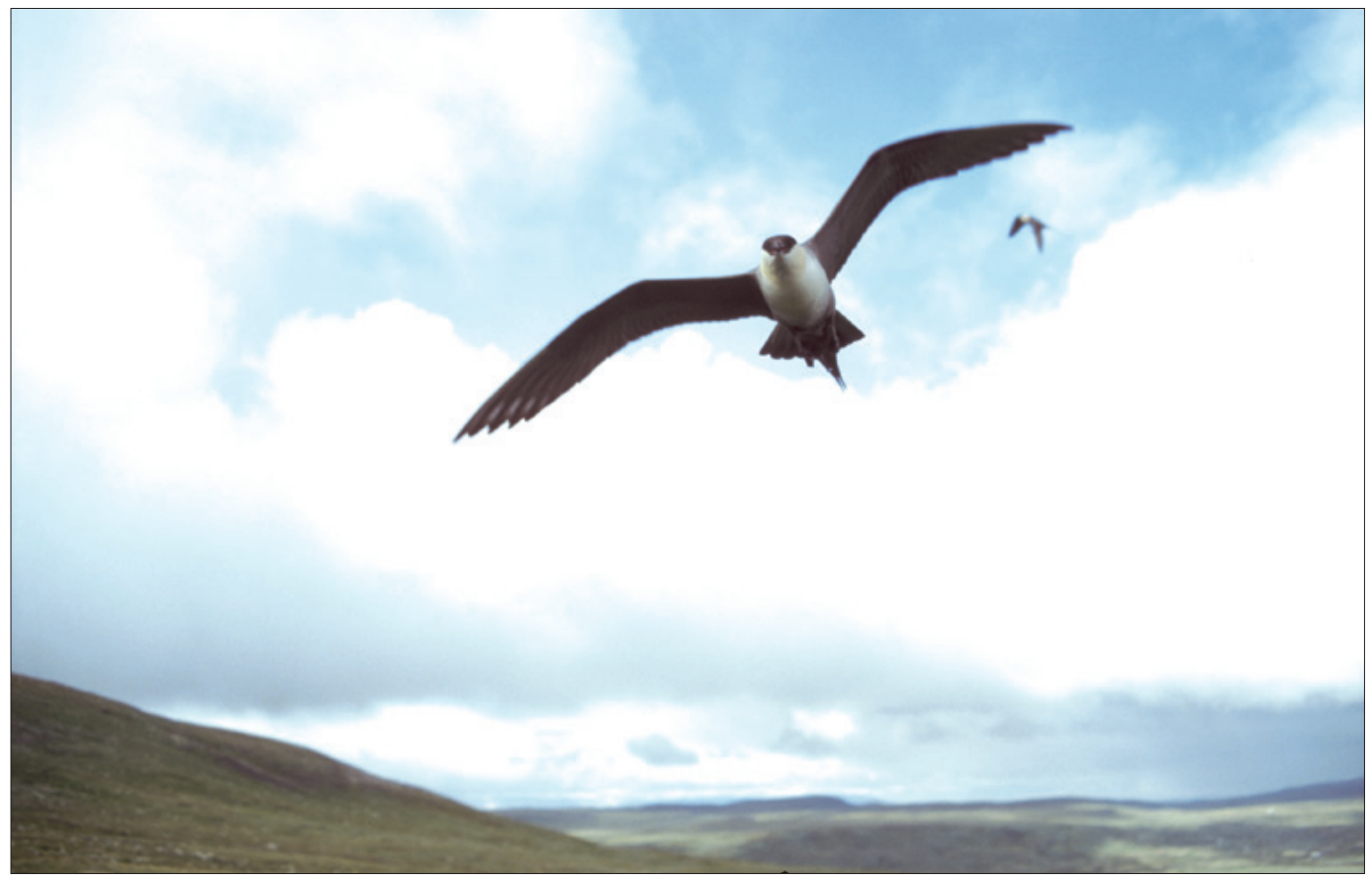

Når fremmede inntar fjelljoens territorium, kan de vare meget aggressive mot inntrengerne. Aggresjonen varierer mye fra par til par. Fuglene på bildet var av de mer hissige på Hardangervidda i 2001. Foto: Frode Falkenberg. 